\title{
FLORISTIC COMPOSITION AND STRUCTURE OF THE DRY AFROMONTANE FOREST AT BALE MOUNTAINS NATIONAL PARK, ETHIOPIA
}

\author{
Haile Yineger ${ }^{1}$, Ensermu Kelbessa ${ }^{2}$, Tamrat Bekele ${ }^{2}$ and Ermias Lulekal ${ }^{3}$ \\ ${ }^{1}$ Department of Biology, Jimma University, PO Box 5195, Jimma, Ethiopia \\ E-mail: haile_mulu@yahoo.com or haile.yineger@ju.edu.et \\ ${ }^{2}$ National Herbarium, Department of Biology, Faculty of Science, Addis Ababa University \\ PO Box 3434, Addis Ababa, Ethiopia \\ ${ }^{3}$ Department of Biology, Debre Berhan University, PO Box 445, Debre Berhan, Ethiopia
}

\begin{abstract}
The floristic composition and structure of the Dry Afromontane Forest at Bale Mountains National Park was studied from July 2003 to June 2004. A total of 90 plots were established at three sites (Adelle, Boditi and Gaysay) at an altitudinal range of 3010-3410 m. The cover abundance values, density, and diameter at breast height and list of species were recorded in each plot. About 230 species belonging to 157 genera and 58 families were identified and documented. Analysis of vegetation data revealed 5 homogenous clusters. The densities of trees in the diameter class $>2 \mathrm{~cm}$ were 766 and 458 individuals ha-1 ${ }^{-1}$ Adelle and Boditi forests, respectively. The basal areas were about 26 and $23 \mathrm{~m}^{2} \mathrm{ha}^{-1}$ in Adelle and Boditi forests, respectively. About $43 \%$ of the basal area in Adelle and 57 in Boditi forests were contributed by Juniperus procera and Hagenia abyssinica, respectively. Both Adelle and Boditi forests were found at an earlier secondary stage of development and had, more or less, a similar trend of development. The population structures of tree species were assessed and these had clearly signalled the occurrence of excessive cutting of selected diameter classes of ecologically, economically and medically important tree species for various purposes, particularly for construction.
\end{abstract}

Key words/phrases: Bale Mountains, floristic composition, plant community, vegetation structure

\section{INTRODUCTION}

The highland area of Ethiopia was once covered with extensive forest resources (EMA, 1988). However, the country has lost these resources at an alarming rate due to various reasons. According to EFAP (1994), the annual loss of forest resources of the country is estimated between 150,000 and 200,000 ha.

The most important reason behind the rapid deforestation rate in the country is the everincreasing human population growth. This rapid increase in human population is associated with a very high demand for agricultural and grazing lands, forest resources for firewood, charcoal, timber, construction, and many other purposes. Fire, inappropriate investment activities, and lack of viable land use policy have also been key factors for the rapid decline of forests in the country (Friis, 1992; Taye Bekele et al., 1999).

The Bale Mountains National Park (BMNP) is primarily established for the conservation of the critically endangered Ethiopian endemic mammal species, the Ethiopian Wolf (Canis simensis) and Mountain Nyala (Tragelaphus buxtoni). Nonetheless, the park has extremely diverse habitats that are mainly the results of altitudinal variations, and these have supported so many other endemic flora and fauna (Miehe and Miehe, 1994). Moreover, the park is a site for the origin of numerous water bodies that are incredibly vital for the livelihood of both the lowland and highland dwellers (Williams, 2002). However, the BMNP and many other protected areas in Ethiopia are not well managed and their resources are being exploited unsustainably (Shibru Tedla, 1995).

For effective management and conservation of this unique ecosystem of the country, there is an urgent need to develop a sound management plan, and this, in turn, requires detailed baseline information on the ecology of the area. Menassie Gashaw and Masresha Fetene (1996) studied the plant communities of the Afroalpine vegetation of Sanetti plateau. Miehe and Miehe (1994) studied the Ericaceous forests of the Bale Mountains. The National Herbarium (2004) carried out a general biodiversity assessment of the park and surrounding areas. Nevertheless, the floristic composition, plant community and structural analysis of the Dry Afromontane Forest in the Bale Mountains National Park have not previously been investigated. Therefore, the present study was 
conducted to determine the floristic composition, identify plant communities and carryout structural analysis of the Dry Afromontane Forest in the park, and this is believed to contribute a lot to the effort being made in the development of a sound management plan for effective conservation of the park resources.

\section{MATERIALS AND METHODS}

\section{Study area}

The study area is located in Oromia National Regional State, Bale Zone, between latitudes $07^{0} 05.98^{\prime}-07^{0} 08.99^{\prime} \mathrm{N}$ and longitudes 039043.43'$039^{0} 45.39^{\prime} \mathrm{E}$ (Fig. 1). The altitudinal range of this area lies between $3010-3410 \mathrm{~m}$ a.s.l. The lava outpourings of the Miocene and Oligocene geological periods were responsible for the formation of the Bale Mountains (Mohr, 1963). The rocks formed from these trapean lavas mainly consist of trachytes, with some amounts of rhyolytes, tuffs, basalts, and associated agglomerates (Morton, 1976). The trachytic and basaltic rocks weather predominantly to the fairly fertile loam soils that are of reddish-brown to black in colour (Miehe and Miehe, 1994).
The study area has a bimodal rainfall distribution from March to October, with the highest rain falling in April and then from July to October (Fig. 2) (NMSA, Personal communication). The dry season extends from November to February. The mean annual rainfall is $1218.64 \mathrm{~mm}$. The mean annual minimum and maximum temperatures of the area are $2.36^{\circ} \mathrm{C}$ and $15.5^{\circ} \mathrm{C}$, respectively. The lowest and highest values of mean monthly minimum temperature were recorded in December $\left(-1^{\circ} \mathrm{C}\right)$ and August $\left(6.1^{\circ} \mathrm{C}\right)$ respectively. The corresponding values for the mean monthly maximum temperature were observed in October $\left(14^{\circ} \mathrm{C}\right)$ and February $\left(21.3^{\circ} \mathrm{C}\right)$, respectively.

The vegetation in the northern part of the Bale Mountains forms the southern margin of the 'widespread, largely undifferentiated Afromontane forest area' of central and north Ethiopia (Miehe and Miehe, 1994). Altitudinal and associated climatic variations along this site have resulted in the formation of four distinct vegetation zones each of which has its own unique flora and fauna. These are the grasslands of Gaysay valley and Dinsho, the Juniperus-Hagenia forests, the Erica or heather belt, and the Afro-Alpine moorlands of the plateau and the central peaks (Williams, 2002).

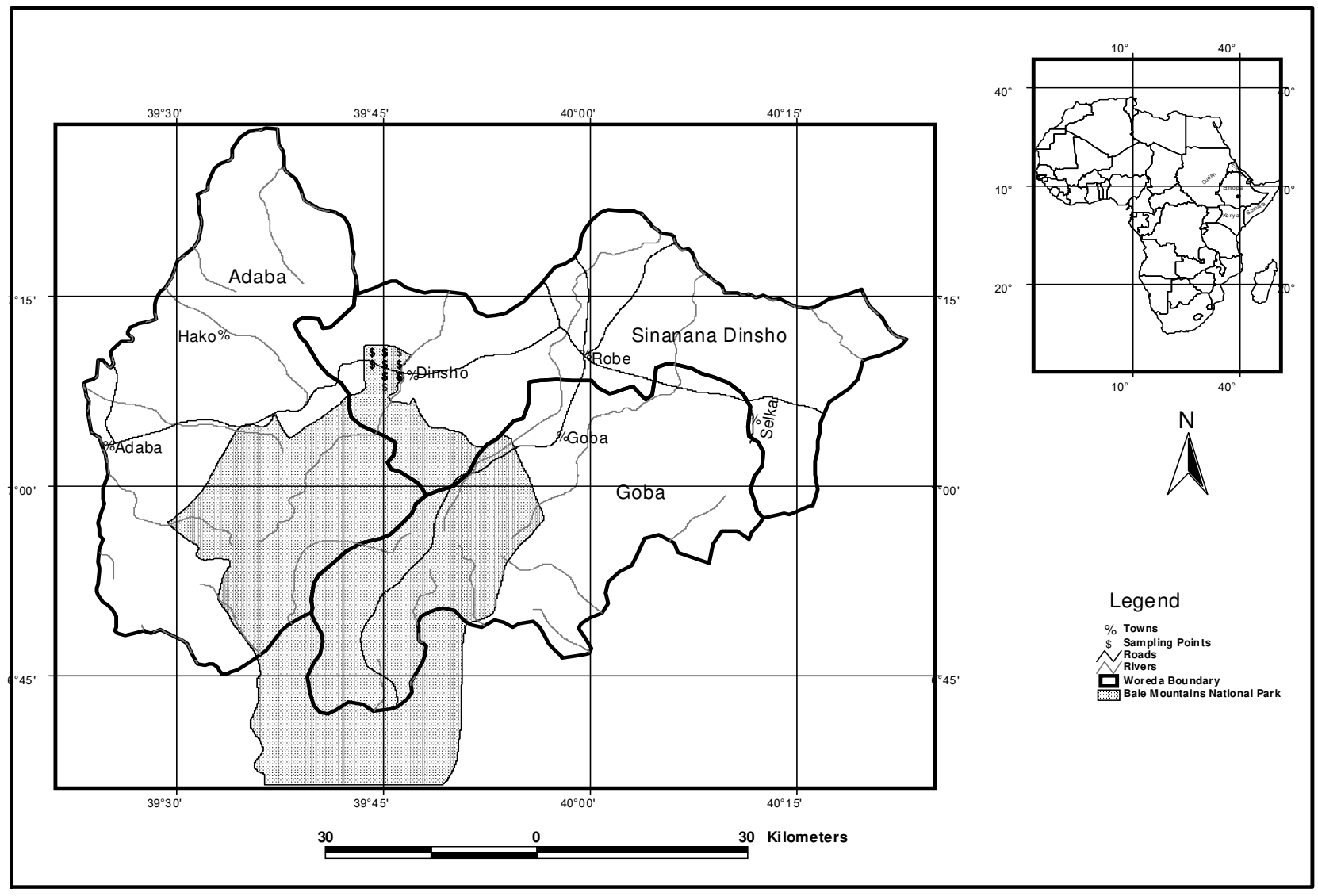

Fig. 1. Map showing the study area. 


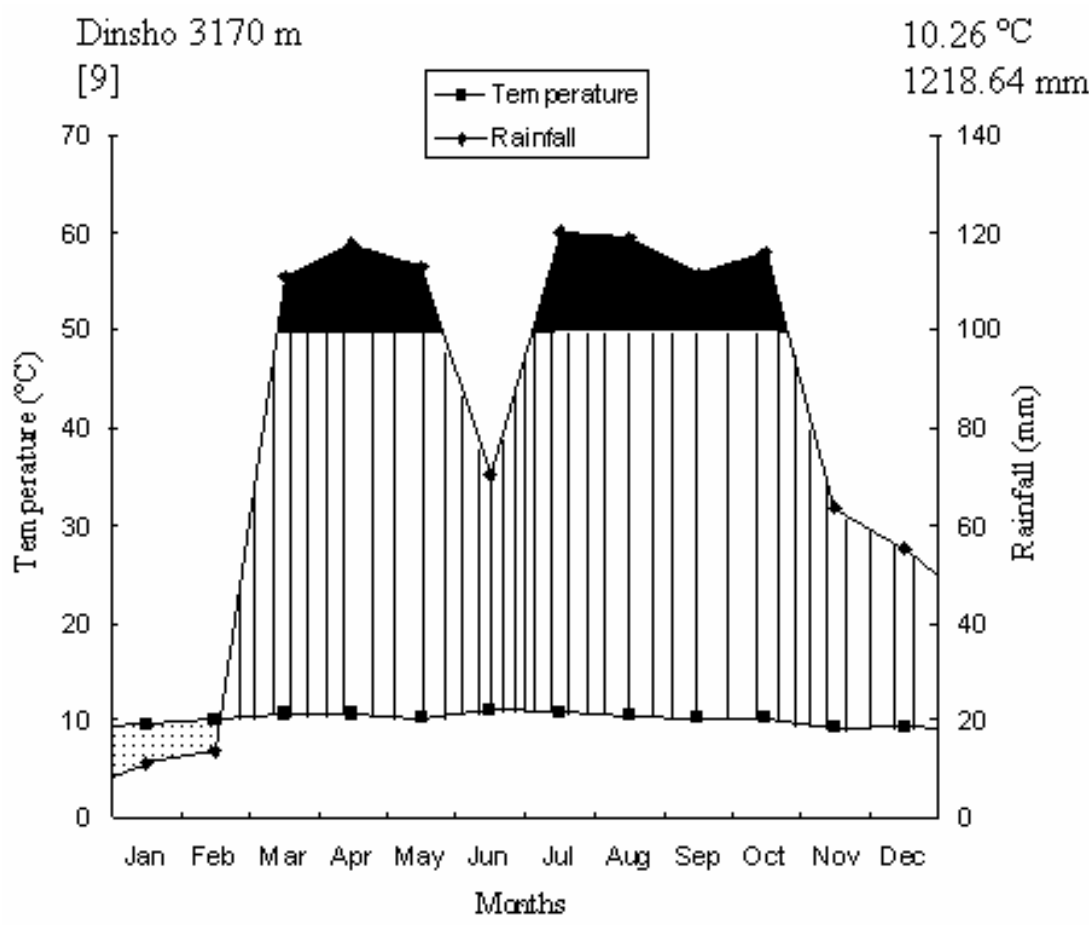

Fig. 2. Climadiagram (after Walter, 1985) showing rainfall distribution and temperature variation from 1994-2002 at Dinsho (BMNP Headquarters). Data source: National Meteorological Service Agency.

\section{Site selection and plot establishment}

A reconnaissance survey was made from 30 July to 2 August 2003 to obtain an impression on the general physiognomy of the vegetation and identify sampling sites in the study area. The fieldwork was done between 3 August and 12 August 2003, September and November 2003, and January and June 2004. Based on the reconnaissance survey, three sites (Adelle and Boditi forests, and Gaysay grassland) were chosen within the park area some 5 to $7 \mathrm{~km}$ northeast of the Bale Mountains National Park (BMNP) headquarters. These sites were chosen because they were relatively better protected and the extent of human disturbance was relatively less than in the other areas of the Dry Afromontane Forest in the park. The Gaysay grassland is almost a flat area that lies between Adelle and Boditi. The altitudinal ranges of Gaysay grassland, Boditi and Adelle are 3010-3060 m, 3060-3410 m, and 3070-3350 m above sea level, respectively.

Five line transects were laid on each of the two sites (Adelle and Boditi) beginning from the Ericaceous zone to the edge of the forests. The distance between transects was $500 \mathrm{~m}$. A total of 32 (Adelle) and 36 (Boditi) nested plots ( $30 \times 30 \mathrm{~m}$ for trees, $5 \times 5 \mathrm{~m}$ for shrubs and $2 \times 2 \mathrm{~m}$ for herbs) were established at every $35 \mathrm{~m}$ drop in altitude along these transects.
Gaysay grassland shows little altitudinal variation, and therefore, floristic data were collected from this site following Kumelachew Yeshitela and Tamrat Bekele (2002) through subjectively selected homogenous representative stands. In such a way, 22 nested plots $(5 \times 5 \mathrm{~m}$ for shrubs and $2 \times 2 \mathrm{~m}$ for herbs) were analysed from this site.

Altitude was measured for each sample plot using 'Pretel' digital altimeter. GPS readings of latitude and longitude coordinates were also recorded for each plot.

\section{Vegetation data collection}

A complete list of herbs (plants whose stem does not produce woody, persistent tissue), shrubs (woody plants having several stems at or near the base of the plant and less than $3 \mathrm{~m}$ tall), lianas (woody plants which use trees and other means to climb over the canopy) and trees (woody plants having a dominant stem and more than $6 \mathrm{~m}$ tall) were made in each plot. The occurrence of lichens, bryophytes and vascular epiphytes were also noted. The 1-9 modified Braun-Blanquet scale (van der Maarel, 1979) was used to estimate the coverabundance values of tree and shrub species.

The diameter at breast height (DBH), i.e., $1.3 \mathrm{~m}$ from ground was estimated for each tree and shrub species by measuring circumference and later converting to obtain estimates of $\mathrm{DBH}$ 
following Abate Ayalew (2003). In cases where the tree or shrub branched at about breast height, the circumference was measured separately for the branches. Trees and shrubs with DBH $>2 \mathrm{~cm}$ were counted in each plot.

Voucher specimens of plants were collected from the study area, allotted collection numbers, pressed, and dried for identification at the National Herbarium (ETH), Addis Ababa University. Some of the plants were identified in the field while most were identified at the National Herbarium by comparing with already identified herbarium specimens and using taxonomic keys in the Flora of Ethiopia and Eritrea (Hedberg and Edwards, 1989; 1995; Edwards et al., 1995; 2000; Hedberg et al., 2003; Hedberg et al., 2004). Voucher specimens were eventually kept at the National Herbarium.

\section{Data analyses}

Vegetation data was analysed using TWINSPAN program version 1.0 (Hill, 1979). In this program the following options were chosen: Number of pseudospecies cut levels 3; Cut levels $0 \quad 6 \quad 10$; minimum group size for division 3; maximum number of indicators per division 10; maximum number of species in final tabulation 55; weights for levels of pseudospecies 13 3; and all the rest of the different options in this program were set to default values.

The plots were thus grouped into clusters by this program, and the community types distinguished from the output were further refined in a synoptic table. The product of average cover-abundance values of a species and its frequency in a community type were taken as the synoptic values of the species in the community type (van der Maarel et al., 1987). Eventually, the community types were named after one or more dominant and/or characteristic species.

Vegetation data was also subjected to hierarchical agglomerater cluster analysis in PCORD 5.0 (McCune and Mefford, 1999) with the cluster setup of Sorenson's (Bray-Curtis) distance measure and flexible beta (cluster flexible beta value $=-0.25$ ) group linkage method so as to obtain dendrogram of communities along with respective sample plots.

Structural analysis was performed on the basis of density, frequency, DBH and basal area per hectare. Ten DBH classes (2-10, 10-20, 20-30, 30-50, 50-70, 70-90, 90-110, 110-130, 130-150, and >150 $\mathrm{cm})$ were constructed after Kitessa Hundera (2003), and the density distribution of tree and shrub species were computed in each class. The distribution of the size classes was evaluated by computing the density of individuals with DBH $>10$ $\mathrm{cm}$ and $>20 \mathrm{~cm}$ as well as the ratio of the former to the latter. According to Grubb et al. (1963), the ratio of 'density at DBH class $>10 \mathrm{~cm}$ ' to 'density at DBH class $>20 \mathrm{~cm}^{\prime}$ can be used as a measure of the distribution of the different size classes. The patterns of species population structure detected were interpreted as a sign for the alteration in population dynamics in the forests (Popma et al., 1988).

The following structural parameters were calculated for some species following MuellerDombois and Ellenberg (1974) and Martin (1995):

Percent frequency of a species $=$ the number of plots in which that species occurs/total number of plots $X 100$

Relative frequency $=$ Frequency of species A/total frequency of all species $X 100$

Density of a species $=$ the number of individuals of that species/area sampled

Relative density $=$ Density of species $\mathrm{A} /$ total density of all species X 100

Basal area $\left(\mathrm{m}^{2}\right)=(\mathrm{DBH} / 200)^{2} \pi$

where DBH is the diameter at breast height $(\mathrm{cm})$, $\pi=3.14$

Dominance $=$ Total of basal area $/$ area sampled

Relative dominance $=$ Dominance of species A/total dominance of all species X 100

Importance Value Index = Relative density + Relative frequency + Relative dominance.

\section{RESULTS AND DISCUSSION}

\section{Floristic composition}

A total of 230 plant species belonging to 157 genera and 58 families were identified in this study indicating that the area was more rich in its plant diversity (see Appendix I) than Jibat Forest (Tamrat Bekele, 1993), Dakata Valley Forest (Demel Teketay, 1995a), Chilimo Forest (Tadesse Woldemariam, 1998), Dodola Forest (Kitessa Hundera, 2003), Denkoro Forest (Abate Ayalew, 2003), Mena Angetu Forest (Ermias Lulekal, 2005), and Yayu Forest (Tadesse Woldemariam et al., 2008). Out of the total plant species identified, about 63 species $(35.8 \%)$ were found to have ethnomedicinal use by the local people and their detailed ethnobotanical descriptions are already reported elsewhere (see Haile Yineger et al., 2007; 
2008). Recorded plant species compositions served as good evidences to categorize the study area as one of the largely undifferentiated Afromontane forest types described by Friis (1992). Asteraceae was the most dominant plant family with 39 species, followed by Poaceae with 30 species. The family Asteraceae has been reported as dominant in the Afromontane flora of Ethiopia (e.g., Mesfin Tadesse, 2004; Ermias Lulekal, 2005) as well as other North-eastern African countries (e.g., Bytebier and Bussmann, 2000; Abdel-Ghani and Abdel-Khalik, 2006). This could be attributed to its efficient and successful dispersal strategies as well as adaptation to a wide range of ecological conditions. The most dominant growth forms were herbs with 183 species (79\%) followed by shrubs with 26 species (11\%). The other growth forms include epiphytes with 9 species $(3.9 \%)$, trees with 6 species (2.6\%), herbaceous climbers with 5 species $(2.2 \%)$ and lianas with 3 species (1.3\%).

\section{Plant community types}

Analysis of vegetation data using TWINSPAN program revealed five clusters that could be recognized as plant community types. Five community groups were also identified in the dendrogram output of the hierarchical agglomerate classification in PCORD 5.0 (McCune and Mefford, 1999). Community groups in this dendrogram were determined at 25\% information remaining within groups (see Appendix II). One or a combination of dominant or characteristic species having high synoptic values in the type was/were used to name these plant community types (Table 1). The description and altitudinal distribution of these plant community types is given below. Unfortunately this study did not address analyses of a range of possible environmental variables except altitude that could shape the distribution of identified plant communities.

\section{Erica arborea community}

This community type was dominated by Erica arborea and was found at an altitudinal range of 3130-3410 m. A study conducted at Wof-Washa Forest (Demel Teketay, 1995b) also showed particular dominance of this species in the aforementioned altitudinal zone. Senecio ochrocarpus, Echinops macrochaetus, and Carduus leptacanthus were characteristic species in this community. Significant numbers of Juniperus procera, Helichrysum splendidum, Ferula communis, and Kniphofia foliosa were also found in this type. Species such as Myrsine melanophloeos, Hagenia abyssinica, Solanum marginatum, Salvia merjame, and
Senecio ragazzii, were common whereas Hypericum revolutum, Helichrysum quartitianum, Solanum garae and Hypericum peplidifolium were rare in this community type.

2. Juniperus procera -Myrsine melanophloeos Hagenia abyssinica community

This community type lied at an altitudinal range of 3060-3370 m, and Juniperus procera and Hagenia abyssinica trees mostly dominated the upper canopy. Very significant proportions of Hypericum revolutum, Myrsine melanophloeos, and Kniphofia foliosa were also found. Characteristic species in this community included Juniperus procera, Euphorbia dumalis and Rosa abyssinica. Other common species that occurred in the understory layer included Solanum marginatum, Erica arborea, Helichrysum splendidum, Ferula communis and Salvia merjame.

3. Hypericum revolutum - Myrsine melanophloeos - Hagenia abyssinica - Solanum marginatum community

The altitudinal range of this community type lied between $3090 \mathrm{~m}$ and $3350 \mathrm{~m}$ and Hypericum revolutum and Hagenia abyssinica trees dominated its upper canopy. Myrsine melanophloeos and Solanum marginatum were also dominant. Kalanchoe petitiana, Discopodium eremanthum and Solanum marginatum were characteristic species of this type. Other important species in this community type comprised Kniphofia foliosa, Salvia merjame, Senecio ragazzii, Euphorbia dumalis and Ferula communis. Some species like Erica arborea, Juniperus procera, Rosa abyssinica, Malva verticillata, and Echinops hoehnelii occurred infrequently.

\section{Artemisia afra - Nepeta azurea community}

This community type was found at an altitudinal range of 3010-3050 m, and its upper layer was dominated by Artemisia afra and Helichrysum splendidum. Nepeta azurea was the characteristic species and highly associated with Artemisia afra. Kniphofia foliosa and Ferula communis were also common. Plant species like Hypericum revolutum, Euphorbia depauperata, Hypericum peplidifolium, Astragalus atropilosulus, and Rubus erlangeri were rarely seen.

5. Ferula communis - Helichrysum splendidum community

This community type was found at an altitudinal range of 3010-3060 m, and Ferula communis was the dominant species. Substantial numbers of Salvia 
merjame, Helichrysum splendidum, Kniphofia foliosa and Artemisia afra were also present. Euphorbia depauperata and Helichrysum foetidum were other common species whereas Hypericum revolutum and Hypericum peplidifolium were rare.

Communities 1, 2, 3, 4 and 5 were found to accommodate about 35, 44, 40, 25 and 24 ethnomedicinal plant species, respectively (Haile Yineger et al., 2007; 2008). Community type 1 was found near the top of Boditi hill while community type 2 occurred in Adelle. Community type 3 was partially found in Adelle but it formed the major tree layer in Boditi Forest. Friis (1992) has indicated the occurrence of such communities at higher elevations in the largely undifferentiated Afromontane forests of Ethiopian highlands. The remaining two communities were found in between the two forests at Gaysay grassland.

Altitude has been investigated in a number of studies (e.g., Tamrat Bekele, 1993; Miehe and Miehe, 1994; Demel Teketay, 1995b; Sebsebe Demissew, 1988; Abate Ayalew, 2003; Ermias Lulekal, 2005; Tadesse Woldemariam et al., 2008;) as one of the major environmental gradients that could shape the species composition and distribution of plant communities. This environmental variable seems to have significant contribution in the current study area in determining plant community compositions and zones despite the presence of overlaps with some community types (see altitudinal distribution of the aforementioned five communities)

Table 1. Synoptic table of species reaching a value of $\geq 0.1$ in at least one community type.

\begin{tabular}{|c|c|c|c|c|c|}
\hline Cluster Number & 1 & 2 & 3 & 4 & 5 \\
\hline Cluster Size & 11 & 36 & 22 & 11 & 9 \\
\hline Echinops macrochaetus & 0.3 & 0 & 0 & 0 & 0 \\
\hline Senecio ochrocarpus & 1.2 & 0 & 0 & 0 & 0 \\
\hline Helichrysum quartitianum & 0.1 & 0 & 0 & 0 & 0 \\
\hline Carduus leptacanthus & 0.2 & 0 & 0 & 0 & 0 \\
\hline Solanum garae & 0.1 & 0 & 0 & 0 & 0 \\
\hline Erica arborea & 8.0 & 0.9 & 0.1 & 0 & 0 \\
\hline Juniperus procera & 0.8 & 4.9 & 0.1 & 0 & 0 \\
\hline Hypericum revolutum & 0.1 & 4.9 & 5.1 & 0.1 & 0.1 \\
\hline Myrsine melanophloeos & 0.3 & 4.7 & 3.7 & 0 & 0 \\
\hline Hagenia abyssinica & 0.3 & 2.0 & 2.0 & 0 & 0 \\
\hline Solanum marginatum & 0.3 & 0.4 & 3.1 & 0 & 0 \\
\hline Salvia merjame & 0.3 & 0.2 & 0.5 & 0 & 1.7 \\
\hline Kniphofia foliosa & 0.4 & 2.8 & 1.2 & 1.4 & 1.3 \\
\hline Euphorbia dumalis & 0 & 0.8 & 0.3 & 0.1 & 0 \\
\hline Malva verticillata & 0 & 0 & 0.1 & 0.1 & 0 \\
\hline Echinops hoehnelii & 0 & 0 & 0.1 & 0 & 0 \\
\hline Discopodium eremanthum & 0 & 0 & 0.7 & 0 & 0 \\
\hline Kalanchoe petitiana & 0 & 0 & 0.9 & 0 & 0 \\
\hline Senecio ragazzii & 0.3 & 0 & 0.3 & 0 & 0 \\
\hline Hypericum peplidifolium & 0.1 & 0 & 0 & 0.1 & 0.1 \\
\hline Rosa abyssinica & 0.0 & 0.5 & 0.1 & 0 & 0 \\
\hline Artemisia afra & 0 & 0 & 0 & 4.3 & 1.2 \\
\hline Nepeta azurea & 0 & 0 & 0 & 4.2 & 0 \\
\hline Helichrysum splendidum & 0.6 & 0.4 & 0 & 2.5 & 1.8 \\
\hline Ferula communis & 0.4 & 0.3 & 0.2 & 0.2 & 4.8 \\
\hline Euphorbia depauperata & 0 & 0 & 0 & 0.1 & 0.3 \\
\hline Helichrysum foetidum & 0 & 0 & 0 & 0 & 0.4 \\
\hline Astragalus atropilosulus & 0 & 0 & 0 & 0.1 & 0 \\
\hline Rubus erlangeri & 0 & 0 & 0 & 0.1 & 0 \\
\hline
\end{tabular}




\section{Density of tree and shrub species}

The densities of trees and shrubs were 898 individuals ha-1 in Adelle Forest and 498 individuals ha ${ }^{-1}$ in Boditi Forest at DBH $>2 \mathrm{~cm}$ (Table 2). These densities are low compared to some other Afromontane forests in Ethiopia, for example, Kimphee Forest (3059 stems ha ${ }^{-1}$ ) (Feyera Senbeta and Demel Teketay, 2003), MashaAnderacha Forest (1709 stems ha-1) (Kumlachew Yeshitela and Taye Bekele, 2003), and Dindin Forest (1750 stems ha-1) (Simon Shibru and Girma Balcha, 2004). This could be attributed to variations in landscape topographic gradients as well as habitat qualities linked to ecological requirements of component tree and shrub species in the respective forests. At $\mathrm{DBH}>10 \mathrm{~cm}$, the densities of trees and shrubs were 432 and 283 individuals ha- ${ }^{-1}$ in Adelle and Boditi forests, respectively. The corresponding densities at DBH $>20 \mathrm{~cm}$ were 174 and 125 individuals ha-1 in Adelle and Boditi forests, respectively.

The density of trees alone at the DBH class $>2 \mathrm{~cm}$ was 766 individuals ha-1 in Adelle Forest, accounting for $85.3 \%$ of the total density of trees and shrubs (Table 2). This was actually greater than density of tree species at Mana Angetu Forest (408 stems ha-1) (Ermias Lulekal, 2005). The corresponding density in Boditi Forest was 458 individuals ha $^{-1}$, representing $92 \%$ of the total density of trees and shrubs. Tree density in Adelle Forest at the DBH class $>10 \mathrm{~cm}$ was 413 individuals ha $^{-1}$, accounting for $96 \%$ of the total density of trees and shrubs. The corresponding value in Boditi Forest at the same DBH class was 256 individuals ha $^{-1}$, and it accounted for $91 \%$ of the total density of trees and shrubs. Similarly, at the DBH class $>20$ $\mathrm{cm}$, the tree density in Adelle Forest was 164 individuals ha $^{-1}$, representing $94 \%$ of the total density of trees and shrubs while that of Boditi Forest was 114 individuals ha-1, and this accounted for $91 \%$ of the total density of trees and shrubs.

The ratio of 'density at DBH class $>10 \mathrm{~cm}$ ' to 'density at DBH class $>20 \mathrm{~cm}^{\prime}$ in Adelle was 2.52 and 2.25 in Boditi (Table 2). These comparisons indicated that both Adelle and Boditi forests were dominated by more numbers of small-sized individuals. The dominance of small-sized individuals was slightly greater in Adelle than in Boditi. This predominance of small-sized individuals was largely due to the high density of Myrsine melanophloeos in Adelle Forest and Hypericum revolutum in Boditi Forest. Similar conditions were reported from Dindin Forest where Olinia rochetiana and Myrsine africana were dominant (Simon Shibru and Girma Balcha, 2004); and in Masha-Anderacha Forest where Cyathea manniana dominated (Kumelachew Yeshitela and Taye Bekele, 2003). Another major reason was due to the fact that the trees and shrubs were found at their upper altitude limits, i.e., $3010-3410 \mathrm{~m}$. Selective cutting of medium sized individuals for a variety of purposes, mainly for construction, was the other reason.

Table 2. Density of trees and shrubs in Adelle and Boditi forests with DBH $>2 \mathrm{~cm},>10 \mathrm{~cm}$ and $>20 \mathrm{~cm}$ individuals (Ind.) ha-1.

\begin{tabular}{|c|c|c|c|c|c|c|c|c|c|c|c|c|c|c|}
\hline \multirow[b]{3}{*}{ Species } & \multicolumn{4}{|c|}{$>2 \mathrm{~cm}$} & \multicolumn{4}{|c|}{$>10 \mathrm{~cm}$} & \multicolumn{4}{|c|}{$>20 \mathrm{~cm}$} & \multicolumn{2}{|c|}{$>10 />20 \mathrm{~cm}$} \\
\hline & \multicolumn{2}{|l|}{ Adelle } & \multicolumn{2}{|l|}{ Boditi } & \multicolumn{2}{|l|}{ Adelle } & \multicolumn{2}{|l|}{ Boditi } & \multicolumn{2}{|l|}{ Adelle } & \multicolumn{2}{|l|}{ Boditi } & \multirow{2}{*}{ - Adelle } & \multirow{2}{*}{ Boditi } \\
\hline & Ind. ha-1 & $\%$ & Ind. ha-1 & $\%$ & Ind. ha-1 & $\%$ & Ind. ha-1 & $\%$ & Ind. ha-1 & $\%$ & Ind. ha-1 & $\%$ & & \\
\hline Erica arborea* & 29.17 & 3 & 46.91 & 9 & 19.44 & 5 & 17.28 & 6 & 2.778 & 2 & 4.012 & 3 & 7.00 & 4.31 \\
\hline Hagenia abyssinica* & 12.85 & 1 & 20.37 & 4 & 12.85 & 3 & 18.52 & 7 & 12.85 & 7 & 18.52 & 15 & 1.00 & 1.00 \\
\hline Hypericum revolutum ${ }^{*}$ & 145.5 & 16 & 190.4 & 38 & 128.5 & 30 & 129 & 46 & 60.76 & 35 & 59.26 & 47 & 2.11 & 2.18 \\
\hline Juniperus procera* & 110.4 & 12 & 7.716 & 2 & 110.4 & 26 & 6.173 & 2 & 85.42 & 49 & 6.173 & 5 & 1.29 & 1.00 \\
\hline Myrsine melanophloeos* & 466.3 & 52 & 191.7 & 38 & 139.9 & 32 & 84.57 & 30 & 0 & 0 & 25.62 & 20 & & 3.30 \\
\hline Pittosporum viridiflorum ${ }^{*}$ & 1.736 & 0.19 & 0.617 & 0.12 & 1.736 & 0.4 & 0.617 & 0.22 & 1.736 & 1 & 0.617 & 0.5 & 1.00 & 1.00 \\
\hline Discopodium eremanthum & 4.861 & 1 & 11.11 & 2 & 4.861 & 1 & 9.568 & 3 & 4.514 & 3 & 7.716 & 6 & 1.08 & 1.24 \\
\hline Rosa abyssinica & 6.597 & 1 & 0.926 & 0.19 & 3.472 & 1 & 0.617 & 0.22 & 1.042 & 1 & 0 & 0 & 3.33 & \\
\hline Rubus steudneri & 75 & 8 & 0.309 & 0.06 & 0.346 & 0.08 & 0 & 0 & 0 & 0 & 0 & 0 & & \\
\hline Solanum garae & 2.431 & 0.27 & 1.543 & 0.31 & 0 & 0 & 0 & 0 & 0 & 0 & 0 & 0 & & \\
\hline Solanum marginatum & 42.01 & 5 & 25 & 5 & 9.375 & 2 & 16.05 & 6 & 4.938 & 3 & 3.395 & 3 & 1.90 & 4.73 \\
\hline Maytenus obscura & 0.694 & 0.08 & 0 & 0 & 0.694 & 0.16 & 0 & 0 & 0 & 0 & 0 & 0 & & \\
\hline Solanum anguivi & 0 & 0 & 0.617 & 0.12 & 0 & 0 & 0 & 0 & 0 & 0 & 0 & 0 & & \\
\hline Rubus apetalus & 0 & 0 & 0.617 & 0.12 & 0 & 0 & 0.617 & 0.22 & 0 & 0 & 0 & 0 & & \\
\hline Total & 898 & 100 & 498 & 100 & 432 & 100 & 283 & 100 & 174 & 100 & 125 & 100 & 2.48 & 2.26 \\
\hline Total (Trees alone) & 766 & 85.3 & 458 & 92 & 413 & 96 & 256 & 91 & 164 & 94 & 114 & 91 & 2.52 & 2.25 \\
\hline
\end{tabular}




\section{Diameter at Breast Height (DBH)}

The general pattern of distribution of trees and shrubs in the two forests along the different DBH classes was more or less similar and assumed an inverted J shape (Fig. 3). An inverted J shape population age distribution could somehow indicate a healthy regeneration status of the forests (Demel Teketay, 1997) though analysis of population structures for each individual tree and shrub species could provide more realistic and specific information for conservation measures. Similar overall population patterns were reported for Kimphee Forest (Feyera Senbeta and Demel Teketay, 2003) and for the vegetation in the islands of Lake Ziway (Haileab Zegeye et al., 2006). About $53 \%$ of the individuals in Adelle and about $51 \%$ of the individuals in Boditi forests lied in the DBH class $2-10 \mathrm{~cm}$.

Comparison of the percentage of stems with DBH $<50 \mathrm{~cm}$ in the two forests revealed very close figures, about $97 \%$ for Adelle Forest and about 96\% in Boditi Forest, showing that both Adelle and Boditi possessed many small-sized individuals and very few large-sized individuals. This indicated that Adelle and Boditi were found at an earlier secondary stage of development and had more or less a similar trend of development. This was mainly due to the occurrence of excessive cutting especially during the occupation of the main park area by people from Gojera and Sidamo immigrants between 1974 and 1991 (The National Herbarium, 2004).

\section{Basal area}

The total basal area in Adelle Forest was about $26 \mathrm{~m}^{2}$ ha-1 $^{-1}$ while that in Boditi Forest was about 23 $\mathrm{m}^{2} \mathrm{ha}^{-1}$ (Table 3 ). These are more or less similar figures indicating that both Adelle and Boditi forests were found in a similar trend of development. Basal areas of Adelle and Boditi are much less than reported for many other Afromontane forests in the country, for example, Wof-Washa Forest (about $102 \mathrm{~m}^{2} \mathrm{ha}^{-1}$ ), Jibat Forest (about $50 \mathrm{~m}^{2} \mathrm{ha}^{-1}$ ), Menagesha Forest (about 36 $\mathrm{m}^{2} \mathrm{ha}^{-1}$ ), Chilimo Forest (about $30 \mathrm{~m}^{2} \mathrm{ha}^{-1}$ ) (Tamrat Bekele, 1993), Denkoro Forest $\left(45 \mathrm{~m}^{2} \mathrm{ha}{ }^{-1}\right)$ (Abate Ayalew, 2003) and Mana Angetu Forest $\left(94 \mathrm{~m}^{2} \mathrm{ha}-1\right)$ (Ermias Lulekal, 2005). About $43 \%$ of the basal area in Adelle Forest was contributed by Juniperus procera whereas about $57 \%$ of the basal area at Boditi Forest was contributed by Hagenia abyssinica. These were followed at Adelle Forest by Hagenia abyssinica (about 25\%) and at Boditi Forest by Hypericum revolutum (about 20\%). This implies that Juniperus procera had the highest dominance in Adelle whereas Hagenia abyssinica exhibited the highest dominance in Boditi. Thus, these two species had more numbers of large-sized individuals than the other species. Pittosporum viridiflorum had the least input to the total basal area in both Adelle (0.2\%) and Boditi (about $1 \%$ ) forests.

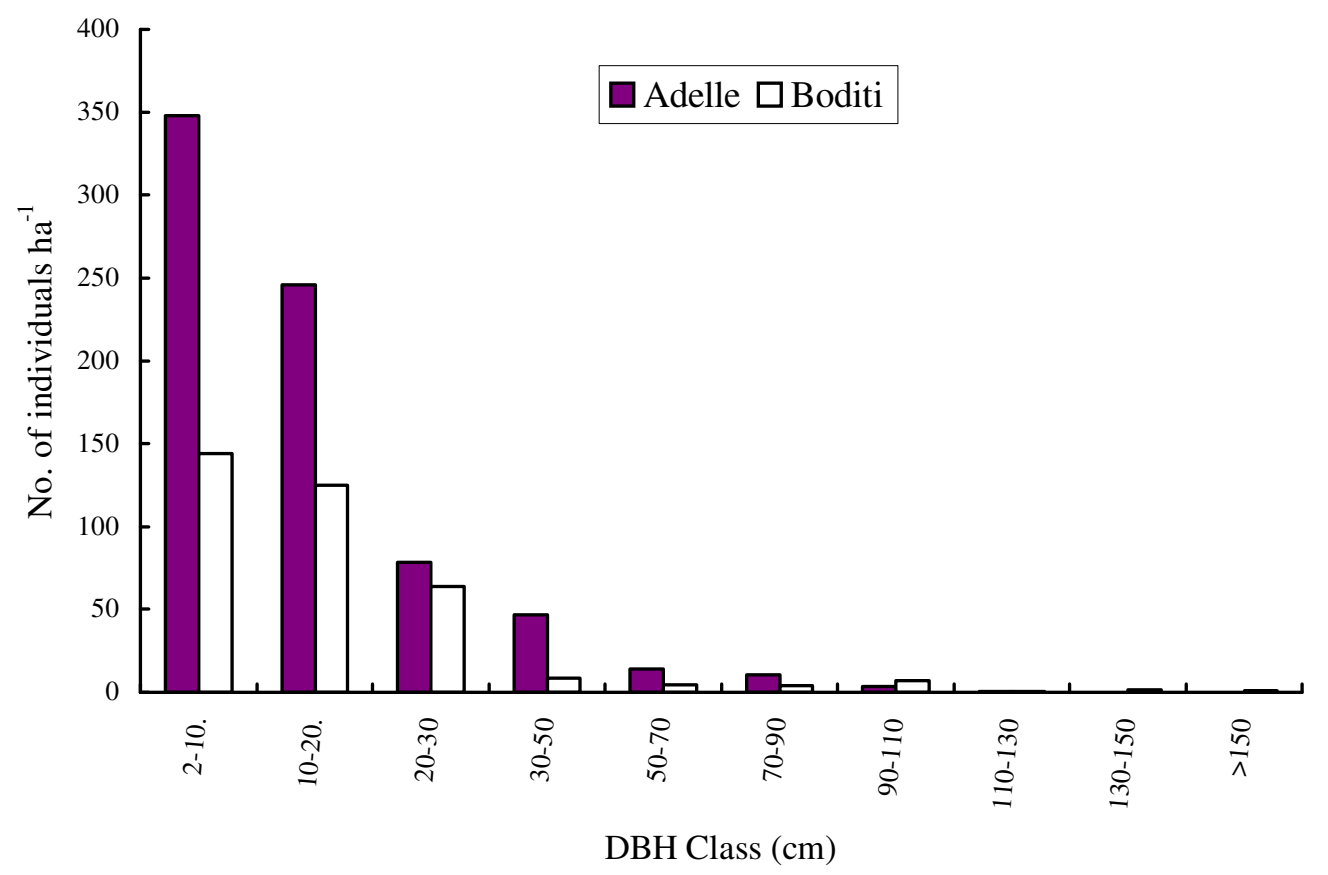

Fig. 3. Distribution of tree and shrub species at Adelle and Boditi forests along the different DBH classes. 
Table 3. Basal area (BA) ( $\left.\mathrm{m}^{2} \mathrm{ha}^{-1}\right)$ and percentage input of tree species in Adelle and Boditi forests.

\begin{tabular}{lllcl}
\hline & \multicolumn{2}{c}{ Adelle } & \multicolumn{2}{c}{ Boditi } \\
\cline { 2 - 5 } Species & $\mathrm{BA}\left(\mathrm{m} 2 \mathrm{ha}^{-1}\right)$ & $\%$ & $\mathrm{BA}\left(\mathrm{m} 2\right.$ ha $\left.^{-1}\right)$ & $\%$ \\
\hline Juniperus procera & 11.54 & 43.74 & 2.29 & 9.83 \\
Erica arborea & 0.37 & 1.40 & 0.68 & 2.90 \\
Hagenia abyssinica & 6.71 & 25.42 & 13.22 & 56.65 \\
Hypericum revolutum & 4.53 & 17.15 & 4.55 & 19.51 \\
Myrsine melanophloeos & 3.19 & 12.08 & 2.33 & 10.00 \\
Pittosporum viridiflorum & 0.06 & 0.22 & 0.26 & 1.11 \\
\hline Total & 26.39 & 100 & 23.34 & 100 \\
\hline
\end{tabular}

The relative importance of tree species in a forest can better be depicted from measurements of basal area than stem counts (Cain and Castro, 1959). Our results showed that Juniperus procera and Hagenia abyssinica were the most important tree species in Adelle Forest whereas Hagenia abyssinica and Hypericum revolutum were the most important species in Boditi Forest.

\section{Importance Value Index (IVI)}

The relative ecological significance and/or dominance of tree species in a forest ecosystem could best be unravelled from analysis of IVI values (Curtis and Mcintosh, 1950). Our results of the calculation of IVI thus helped to identify the dominant tree species in both Adelle and Boditi forests (Table 4). In Adelle Forest, Myrsine melanophloeos exhibited the highest IVI (about 99) followed by Juniperus procera (about 82), indicating that the two species were the dominant tree species in this forest. The highest IVI in Boditi Forest was exhibited by Hypericum revolutum (about 86) followed by Hagenia abyssinica (about 83), which shows that the two species are the dominant in Boditi Forest. Pittosporum viridiflorum was the least dominant species at both forests because it had the least relative dominance, relative density and relative frequency.

\section{Population structure}

Examination of patterns of species population structures could provide valuable formation about their regeneration and/or recruitment status as well as viability status of the population that could further be employed for devising evidence based conservation and management strategies (Demel Teketay, 2005; Abrham Abiyu et al., 2006). Various patterns of species population structures have been reported for different species in other Afromontane forests of the country (e.g., Demel Teketay, 1997; Abate Ayalew, 2003; Feyera Senbeta and Demel Teketay, 2003; Kumlachew Yeshitela and Taye Bekele, 2003; Simon Shibru and Girma Balcha, 2004; Ermias Lulekal, 2005; Haileab Zegeye et al., 2006).

Table 4. Importance value index (IVI) OF tree species in Adelle and Boditi forests.

\begin{tabular}{lcccccccc}
\hline & \multicolumn{2}{c}{ Relative Dominance } & \multicolumn{2}{c}{ Relative Density } & \multicolumn{2}{c}{ Relative Frequency } & \multicolumn{2}{c}{ IVI } \\
Species & Adelle & Boditi & Adelle & Boditi & Adelle & Boditi & Adelle & Boditi \\
\hline Juniperus procera & 43.74 & 9.83 & 14.41 & 1.68 & 23.89 & 12.15 & 82.04 & 23.66 \\
Erica arborea & 1.40 & 2.90 & 3.81 & 10.24 & 12.39 & 18.69 & 17.6 & 31.83 \\
Hagenia abyssinica & 25.42 & 56.65 & 1.68 & 4.45 & 11.51 & 21.50 & 38.6 & 82.59 \\
Hypericum revolutum & 17.15 & 19.51 & 18.99 & 41.58 & 25.66 & 25.23 & 61.81 & 86.32 \\
Myrsine melanophloeos & 12.08 & 10.00 & 60.87 & 41.85 & 25.66 & 21.50 & 98.62 & 73.34 \\
Pittosporum viridiflorum & 0.22 & 1.11 & 0.23 & 0.14 & 0.89 & 0.94 & 1.34 & 2.18 \\
Total & 100 & 100 & 100 & 100 & 100 & 100 & 300 & 300 \\
\hline
\end{tabular}


In the current study, the population structure of six tree species (Erica arborea, Myrsine melanophloeos, Juniperus procera, Hypericum revolutum, Hagenia abyssinica and Pittosporum viridiflorum) was determined using their density at the various DBH classes. Consequently, four representative patterns were detected in both Adelle and Boditi forests (Fig. 4). The first pattern indicated a high number of individuals in the first DBH class followed by a progressive decline in the number of individuals with increasing DBH. This pattern, exemplified by Myrsine melanophloeos and Erica arborea (at Boditi), suggests good recruitment and good regeneration (Fig. 4A). A similar pattern was also reported by Demel Teketay (1997) for 17 and 18 species at Gara Ades and Menagesha dry Afromontane forests, respectively. The second pattern, exemplified by Juniperus procera in Boditi, indicated absence or very few numbers of individuals in the lower three DBH classes, few numbers of individuals in the next four DBH classes, absence of individuals in the $8^{\text {th }}$ and $9^{\text {th }} \mathrm{DBH}$ classes and some individuals with $\mathrm{DBH}$ $>150 \mathrm{~cm}$ (Fig. 4B). This pattern indicates hampered regeneration caused by heavy human pressure on the species leading to scarcity of mature individuals that can serve as seed sources. This pattern was more or less similar to population structures of 14 species in Gara Ades and 7 species in Menagesha dry Afromontane forests (Demel Teketay, 1997). The third pattern, exemplified by
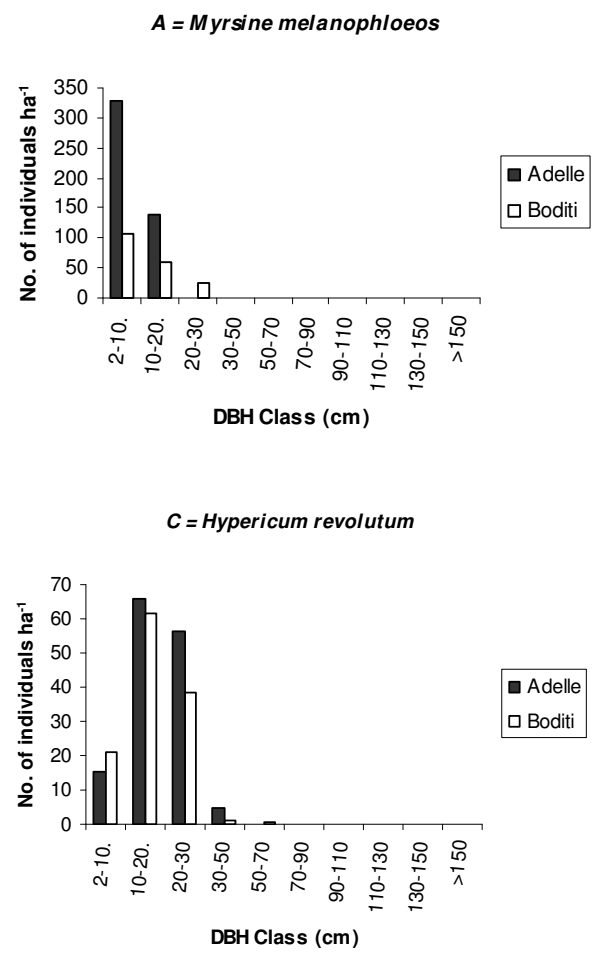

Juniperus procera in Adelle Forest and Hypericum revolutum in both Adelle and Boditi forests, indicated lower number of individuals at the first DBH class, increasing number of individuals in the next four DBH classes and a sharp decline of number of individuals in the next higher DBH classes (Fig. 4B). This pattern shows hampered regeneration, which could be attributed to poor recruitment coupled with selective cutting of individuals in the higher DBH classes. Feyera Senbeta and Demel Teketay (2003) reported similar population patterns in Kimphee Forest represented by Olea welwitschii and Apodytes dimidiata. The fourth pattern, best exemplified by Hagenia abyssinica and Pittosporum viridiflorum, indicates representation of only individuals in the higher DBH classes, suggesting lack of seedling recruitment and hampered regeneration (Figure $4 \mathrm{D})$. The species that exhibited the fourth pattern of population structure are in the verge of local extermination. This pattern of population was nearly comparable to reported structure of Hagenia abyssinica in Dindin Forest (Simon Shibru and Girma Balcha, 2004) suggesting that the species was under sever threat not only in the current study area but also in other similar forests of the country. This raises concerns for its conservation and sustainable utilization.

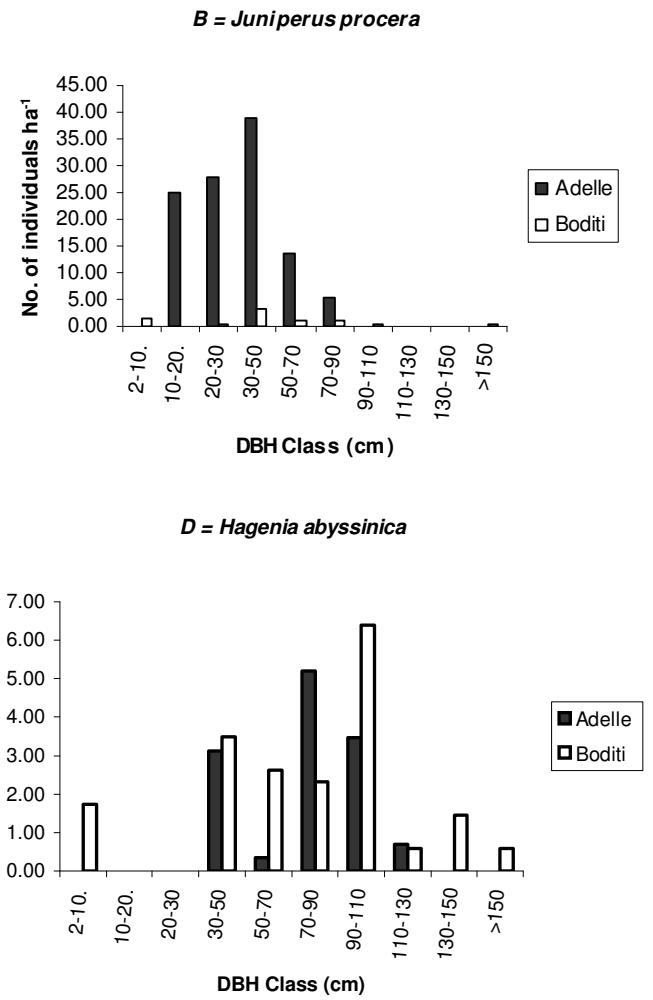

Fig. 4 (A-D). Population structure of representative tree species at Adelle and Boditi forests. 
According to its IVI value, Myrsine melanophloeos was the most dominant tree species at Adelle Forest. However, when the population structure of this species was critically evaluated at the different DBH classes, it was found only at the $2-10 \mathrm{~cm}$ and 10-20 cm DBH classes and was absent in the higher DBH classes. Of course, its largest density was in the DBH class $2-10 \mathrm{~cm}$. The absence of this species at the higher DBH classes was due to the growth nature of the species. The density of this species was higher in Adelle than Boditi forests in the first two DBH classes. The number of individuals declined from DBH classes $20-30 \mathrm{~cm}$ to $30-50 \mathrm{~cm}$ in Boditi Forest whereas there were no individuals in these DBH classes in Adelle Forest (Fig. 4A), which could be attributed to selective cutting of individuals of the species for construction and fencing purposes

The other most dominant tree species in Adelle Forest was Juniperus procera. This species had its highest density in the DBH class $50-70 \mathrm{~cm}$ and there were no individuals in the first DBH class $(2-10 \mathrm{~cm})$. The absence of individuals in the first diameter class indicated its poor regeneration capacity. The population structure of this species assumed a bellshaped distribution with very few individuals at the lower DBH classes, high number of individuals at the middle DBH classes and very few individuals again at the higher DBH classes. The relatively smaller proportions of this species in the DBH classes $10-20 \mathrm{~cm}$ and $20-30 \mathrm{~cm}$ was due to selective removal of individuals for various purposes, mainly for construction. Significant numbers of stumps were observed during data collection. Only few individuals, at DBH classes $2-10 \mathrm{~cm}, 90-110 \mathrm{~cm}$ and $>150 \mathrm{~cm}$, were encountered in Boditi Forest. At Adelle Forest, there were no individuals in these three DBH classes. The major reason for the relative absence of this species in Boditi Forest as compared to Adelle Forest may be due to the difference in the moisture content of the two forests, which in turn is due to the position of the two mountains. Adelle is situated on the leeward side and is relatively dry while Boditi is situated on the windward side and receives wet air. Demel Teketay (1999) mentioned this species as one of the characteristic species in the dry Afromontane forests of the country. This implies that the species prefers relatively dry montane areas like Adelle Forest than wet areas like Boditi Forest. Another possibility might be due to fire treatment requirements of Juniperus procera seeds for germination. Adelle was burnt some years back and seeds of this species were treated with fire that facilitated their germination in that area while
Boditi was not burnt and seeds had no chance for fire treatment causing for the relative absence of the species in Boditi (Rainer W. Bussmann, personal communication). However, the absence of individuals in some of DBH classes in Boditi Forest still requires detailed and independent study.

Hypericum revolutum was the most dominant tree species at Boditi Forest. The density of this species had an increasing trend from the first to the 20-30 $\mathrm{cm}$ DBH classes and a decreasing trend from this point towards the higher DBH classes both at Boditi and Adelle forests (Fig. 4C). Its absence in the higher DBH classes was due to its growth nature. The regeneration capacity of this species was relatively better than Juniperus procera and Hagenia abyssinica.

The second most dominant tree species at Boditi Forest was Hagenia abyssinica. Individuals of this species were absent in the three lower DBH classes in both forests, except very few individuals in the first DBH class in Adelle. The available individuals of this species were relatively mature, and this was true particularly in Boditi Forest than at Adelle Forest (Fig. 4D). This species was, thus, with the poorest regeneration status than the others. This might have happened due to the poor reproductive capacities of its old individuals. The regeneration ecology and reproductive biology of this and the other species should, therefore, be investigated in the study and other similar areas in the country.

\section{ACKNOWLEDGEMENTS}

The World Bank is gratefully acknowledged for provision of financial support through the Conservation and Sustainable Use of Medicinal Plants Project in Ethiopia. The staff members of the National Herbarium are also thanked for letting us use the herbarium facilities. The National Meteorological Service Agency was the source of the climate data without which construction of the climadiagram would have been impossible. We thank Ato Zeleke Kebede, a GIS specialist, for preparing map of the study area. Two anonymous reviewers and associate editor of the journal are thanked for their valuable comments in the earlier versions of this paper.

\section{REFERENCES}

1. Abate Ayalew (2003). Floristic composition and structural analysis of the Denkoro Forest. (Unpublished MSc thesis), Addis Ababa University. 
2. Abdel-Ghani, M.M. and Abdel-Khalic, K.N. (2006). Floristic diversity and phytogeography of the Gebel Elba National Park, South-East Egypt. Turkish Journal of Botany 30:121-136.

3. Abrham Abiyu, Vacik, H. and Glatzel, G. (2006). Population viability risk management applied to Boswellia papyfera (Del.) Hochst in Northeastern Ethiopia. Journal of the Drylands 1(2):98107.

4. Bytebier, B. and Bussmann, R.W. (2000). The vegetation of Mount Nyiru (Samburu district, Kenya): A checklist and synt axonomical survey. Journal of East African Natural History 89:45-71.

5. Cain, S.A. and Castro, G.M.O. (1959). Manual of Vegetation Analyses. Harper and Brothers, New York, 325 pp.

6. Curtis, J.T. and Mcintosh, R.P. (1950). The interrelationship of certain analytic and synthetic phytosociological characters. Ecology 31:434-455.

7. Demel Teketay (1995a). Floristic composition of Dakata Valley, south-eastern Ethiopia, an implication for the conservation of biodiversity. Mountain Research and Development 15:183-186.

8. Demel Teketay (1995b). Floristic composition of Wofwasha natural forest, central Ethiopia: implications for the conservation of biodiversity. Feddes Repertorium 106:127-147.

9. Demel Teketay (1997). Seedling populations and regeneration of woody species in dry Afromontane forests of Ethiopia. Forest Ecology and Management 98:149-165.

10. Demel Teketay (1999). Past and present activities, achievements and constraints in forest genetic resources conservation in Ethiopia. In: Forest Genetic Resources Conservation: Principles, Strategies and Actions, pp. 49-72, (Edwards, S., Abebe Demissie, Taye Bekele and Haase, G., eds). Proceedings. The National Forest Genetic Resources Conservation Strategy Development Workshop, June 21-22, 1999; IBCR and GTZ, Addis Ababa, Ethiopia.

11. Demel Teketay (2005). Seed and regeneration ecology in dry Afromontane forests of Ethiopia: I. Seed production - population structures. Tropical Ecology 46(1):29-44.

12. Edwards, S., Mesfin Tadesse and Hedberg, I. (eds) (1995). Flora of Ethiopia and Eritrea. Volume 2, Part 2. Canellaceae to Euphorbiaceae. The National Herbarium, Addis Ababa University, Addis Ababa and Department of Systematic Botany, Uppsala University, Uppsala.

13. Edwards, S., Mesfin Tadesse, Sebsebe Demissew and Hedberg, I. (eds) (2000). Flora of Ethiopia and Eritrea. Volume 2, Part 1. Magnoliaceae to Flacourtiaceae. The National Herbarium, Addis Ababa University, Addis Ababa and
Department of Systematic Botany, Uppsala University, Uppsala.

14. EMA (1988). National Atlas of Ethiopia. Ethiopian Mapping Authority, Addis Ababa.

15. EFAP (1994). Ethiopian Forestry Action Program. (EFAP), Addis Ababa.

16. Ermias Lulekal (2005). Ethnobotanical study of medicinal plants and floristic composition of the Mena Angetu moist montane forest, Bale, Ethiopia. (Unpublished M.Sc. thesis), Addis Ababa University.

17. Feyera Senbeta and Demel Teketay (2003). Diversity, community types and population structure of woody plants in Kimphee Forest, a virgin nature reserve in Southern Ethiopia. Ethiopian Journal of Biological Sciences 2(2):169-187.

18. Friis, I. (1992). Forest and Forest Trees of Northeast Tropical Africa: Their Natural Habitats and Distribution Pattern in Ethiopia, Djibouti and Somalia. Her Majesty's Stationary Office, London, $396 \mathrm{pp}$.

19. Grubb, P.J., Lloyd, J.R., Pennington, J.D. and Whitmore, J.C. (1963). A comparison of montane and lowland rain forest in Ecuador. I. The forest structure, physiognomy and floristics. Journal of Ecology. 51:567-601.

20. Haile Yineger, Ensermu Kelbessa, Tamrat Bekele and Ermias Lulekal (2007). Ethnoveterinary medicinal plants at Bale Mountains National Park, Ethiopia. Journal of Ethnopharmacology 112:55-70.

21. Haile Yineger, Ensermu Kelbessa, Tamrat Bekele and Ermias Lulekal (2008). Plants used in traditional management of human ailments at Bale Mountains National Park, South-eastern Ethiopia. Journal of Medicinal Plants Research 2(6):132-153.

22. Haileab Zegeye, Demel Teketay and Ensermu Kelbessa (2006). Diversity, regeneration status and socio-economic importance of the vegetation in the islands of Lake Ziway, southcentral Ethiopia. Flora 201:483-489.

23. Hedberg, I. and Edwards, S. (eds.) (1989). Flora of Ethiopia and Eritrea. Volume 3. Pittosporaceae to Araliaceae. The National Herbarium, Addis Ababa University, Addis Ababa and Department of Systematic Botany, Uppsala University, Uppsala.

24. Hedberg, I. and Edwards, S. (eds.) (1995). Flora of Ethiopia and Eritrea. Volume 7. Poaceae (Gramineae). The National Herbarium, Addis Ababa University, Addis Ababa and Department of Systematic Botany, Uppsala University, Uppsala.

25. Hedberg, I., Edwards, S. and Sileshi Nemomissa (eds) (2003). Flora of Ethiopia and Eritrea. Volume 4, Part 1. Apiaceae to Dipsacaceae. The National Herbarium, Addis Ababa University, Addis 
Ababa and Department of Systematic Botany, Uppsala University, Uppsala.

26. Hedberg, I., Friis, I. and Edwards, S. (eds) (2004). Flora of Ethiopia and Eritrea. Volume 4, Part 2. Asteraceae (Compositae). The National Herbarium, Addis Ababa University, Addis Ababa and Department of Systematic Botany, Uppsala University, Uppsala.

27. Hill, M.O. (1979). TWINSPAN. A Fortran Program for Arranging Multivariate Data in an Ordered Twoway Table by Classification of Individuals and Attributes. Ecology and systematics, Cornell University, Ithaca, New York.

28. Kitessa Hundera (2003). Floristic composition and structure of the Dodola Forest, Bale Zone, Oromiya Regional State. (Unpublished M.Sc. thesis), Addis Ababa University.

29. Kumelachew Yeshitela and Tamrat Bekele (2002). Plant community analysis and Ecology of Afromontane and transitional rainforest vegetation of Southwest Ethiopia. SINET: Ethiopian Journal of Science 25(2):155-175.

30. Kumelachew Yeshitela and Taye Bekele (2003). The woody species composition and structure of Masha-Anderacha Forest, South-western Ethiopia. Ethiopian Journal of Biological Sciences 2(1):31-48.

31. Martin, G.J. (1995). Ethnobotany: a Methods Manual. Chapman and Hall, London, UK, 268 pp.

32. McCune, B. and Mefford, M.J. (1999). PC-ORD. Multivariate Analysis of Ecological Data. Version 5.0. MjM Software, Gleneden Beach, Oregon, U.S.A.

33. Menassie Gashaw and Masresha Fetene (1996). Plant communities of the Afroalpine vegetation of Sanetti Plateau, Bale Mountains, Ethiopia. SINET: Ethiopian Journal of Science 19(1):65-86.

34. Mesfin Tadesse (2004). Asteraceae (Compositae). In: Flora of Ethiopia and Eritrea, Volume 4, Part 2 (Hedberg, I., Friis, I. and Edwards, S., eds). The National Herbarium, Addis Ababa University, Addis Ababa and Department of Systematic Botany, Uppsala University, Uppsala.

35. Miehe, S. and Miehe, G. (1994). Ericaceous Forests and Heath Lands in the Bale Mountains of South Ethiopia: Ecology and Man's Impact. Stiftung Walderhaltung in Africa, D-22 113 Hamburg, Rote Brucke 6-15, 206 pp.

36. Mohr, P.A. (1963). The Geology of Ethiopia. Haile Selassie I University Press, Addis Ababa.

37. Morton, B. (1976). A Field Guide to Ethiopian Minerals, Rocks and Fossils. Addis Ababa University Press, Addis Ababa

38. Mueller-Dombois, D. and Ellenberg, H. (1974). Aims and Methods of Vegetation Ecology. Wiley and Sons, New York.
39. Popma, J., Bongers, F. and Meave del Castillo, J. (1988). Patterns in the vertical structure of tropical lowland rain forest of Los Tuxtals, Mexico. Vegetatio 74:81-91.

40. Sebsebe Demissew (1988). The floristic composition of Menagesha State Forest and the need to conserve such forests in Ethiopia. Mountain Research and Development 8:243-247.

41. Shibru Tedla (1995). Protected Areas management crisis in Ethiopia. Walia 16:17-30

42. Simon Shibru and Girma Balcha (2004). Composition, structure and regeneration status of woody species in Dindin Natural Forest, Southeast Ethiopia: An implication for conservation. Ethiopian Journal of Biological Sciences 3(1):15-35.

43. Tadesse Woldemariam (1998). Diversity of woody plants and Avifauna in a dry Afromontane forest on the central plateau of Ethiopia. M.Sc. Thesis. Swedish University of Agricultural Sciences, Uppsala, Sweden.

44. Tadesse Woldemariam, Borsch, T., Denich, M. and Demel Teketay (2008). Floristic composition and environmental factors characterizing coffee forests in Southwest Ethiopia. Forest Ecology and Management 255:2138-2150.

45. Tamrat Bekele (1993). Vegetation ecology of remnant Afromontane forests on central plateau of Shewa, Ethiopia. PhD Dissertation. Uppsala University, Uppsala, Sweden.

46. Taye Bekele, Haase, G. and Teshome Soromessa (1999). Forest genetic resources of Ethiopia: Status and proposed actions. In: Forest Genetic Resources Conservation: Principles, Strategies and Actions, pp. 39-47, (Edwards, S., Abebe Demissie, Taye Bekele and Haase, G., eds). Proceedings. The National forest genetic resources conservation strategy development workshop, June 21-22, 1999, IBCR and GTZ; Addis Ababa, Ethiopia.

47. The National Herbarium (2004). Biodiversity Assessment of the Bale Mountains National Park and Surrounding Areas. Conservation and Sustainable Utilization of Medicinal Plants Project. Addis Ababa, 88 pp.

48. van der Maarel, E. (1979). Transformation of coverabundance values in phytosociology and its effects on community similarity. Vegetatio 39:97-114.

49. van der Maarel, E., Espejel, I. and Moreno-Casasola, P. (1987). Two-step vegetation analysis based on very large data sets. Vegetatio 68:139-143.

50. Walter, H. (1985). Vegetation of the Earth and Ecological System of the Geobiosphere, $3^{\text {rd }}$ ed. Berlin, Heidelberg, New York, 318 pp.

51. Williams, S. (2002). Bale Mountains: A guidebook. EWCP, $52 \mathrm{pp}$. 
Appendix I. List of species in the Dry Afromontane Forest of Bale Mountains National Park. \{Key: GF [growth form], $\mathrm{H}$ [herb], S [shrub], T [tree], Li [liana], H(clim) [herbaceous climber], E [epiphyte], $\mathrm{PH}$ [parasitic herb]\}

\begin{tabular}{|c|c|c|c|c|}
\hline Scientific Name & Family & Local Name & GF & Coll.No \\
\hline Achyranthes aspera $\mathrm{L}$. & Amaranthaceae & Roppe, Qorsa Waranssa & $\mathrm{H}$ & 200 \\
\hline Agrocharis melanantha Hochst. & Apiaceae & Hindriffa, Bobonka & $\mathrm{H}$ & 256 \\
\hline Agrostis sclerophylla C.E. Hubb. & Poaceae & Merga & $\mathrm{H}$ & 356 \\
\hline Ajuga bracteosa Wall. ex Benth. in Wall. & Lamiaceae & & $\mathrm{H}$ & 333 \\
\hline Alchemilla abyssinica Fresen. & Rosaceae & Hindriff & $\mathrm{H}$ & 266 \\
\hline Alchemilla ellenbeckii Engl. & Rosaceae & Hidhanhidhoo & $\mathrm{H}$ & 191 \\
\hline Alchemilla pedata A. Rich. & Rosaceae & Hindriff, Indriif Hindriiffi bala & $\mathrm{H}$ & 264 \\
\hline Alepidea peduncularis Steud. ex A. Rich. & Apiaceae & & $\mathrm{H}$ & 399 \\
\hline Anaptychia liucomeleana Wain & Lichen & & $\mathrm{E}$ & 345 \\
\hline Anchusa affinis R.Br. & Boraginaceae & Burii Jeldessa & $\mathrm{H}$ & 300 \\
\hline Andropogon amethystinus Steud. & Poaceae & Bulto & $\mathrm{H}$ & 384 \\
\hline Andropogon lima (Hack.) Stapf & Poaceae & Wegel Seber (Amh) & $\mathrm{H}$ & 379 \\
\hline Anthemis tigreensis J. Gay ex A. Rich. & Asteraceae & & $\mathrm{H}$ & 287 \\
\hline Anthoxanthum aethiopicum I. Hedberg & Poaceae & & $\mathrm{H}$ & 375 \\
\hline Argyrolobium confertum Polhill & Fabaceae & & $\mathrm{H}$ & 192 \\
\hline Arisaema schimperianum Schott & Araceae & Chobii & $\mathrm{H}$ & 319 \\
\hline Aristida tuniculata Trin. and Rupr. & Poaceae & Laancaa & $\mathrm{H}$ & 370 \\
\hline Artemisia abyssinica Sch. Bip. & Asteraceae & Merga dima & $\mathrm{H}$ & 227 \\
\hline Artemisia afra Jacq. ex Willd. & Asteraceae & Tepeno & $S$ & 286 \\
\hline Asparagus africanus Lam. & Asparagaceae & Seriti & $S$ & 301 \\
\hline Asparagus setaceus (Kunth) Jessap & Asparagaceae & Seriti & $S$ & 79 \\
\hline Asplenium aethiopicum (Burm.f.) Bech. & Aspleniaceae & Qumbuta & $\mathrm{E}$ & 339 \\
\hline Asplenium monanthes $\mathrm{L}$. & Aspleniaceae & Qumbuta & $\mathrm{H}$ & 340 \\
\hline Asplenium theciferum (Kunth) Merr. & Aspleniaceae & & $\mathrm{E}$ & 341 \\
\hline Astragalus atropilosulus (Hochst.) Bange & Fabaceae & Hara & $\mathrm{S}$ & 246 \\
\hline Bartsia abyssinica Hochst. ex Benth. & Scrophulariaceae & Daffura & $\mathrm{H}$ & 294 \\
\hline Bartsia petitiana (A. Rich.) Hemsl. & Scrophulariaceae & & $\mathrm{H}$ & 298 \\
\hline Bidens macroptera (Sch. Bip. ex Chiov.) Mesfin & Asteraceae & Hade gola & $\mathrm{H}$ & 44 \\
\hline Bidens prestinaria (Sch. Bip.) Cuf. & Asteraceae & Hade gola & $\mathrm{H}$ & 289 \\
\hline Brachycorythis buchananii (Schltr.) Rolfe & Orchidaceae & Shumbura gala & $\mathrm{H}$ & 310 \\
\hline Bromus pectinatus Thunb. & Poaceae & Alanmuressa & $\mathrm{H}$ & 388 \\
\hline Campanula edulis Forssk. & Campanulaceae & Rirmu & $\mathrm{H}$ & 303 \\
\hline Cardamine hirsuta L. & Brassicaceae & Biribina & $\mathrm{H}$ & 234 \\
\hline Cardamine obliqua A. Rich. & Brassicaceae & Raffuu simbira & $\mathrm{H}$ & 242 \\
\hline Carduus nyassanus (S. Moore) R.E. Fries & Asteraceae & Qore Haree & $\mathrm{H}$ & 49 \\
\hline Carduus leptacanthus Fresen. & Asteraceae & Qore Haree & $\mathrm{H}$ & 398 \\
\hline Carex bequaertii De Wild. & Cyperaceae & Alanmuressa & $\mathrm{H}$ & 368 \\
\hline Carex chlorosaccus C.B. Clarke & Cyperaceae & & $\mathrm{H}$ & 383 \\
\hline Carex conferta Hochst. ex A. Rich. & Cyperaceae & Alando, Alanmuressa & $\mathrm{H}$ & 362 \\
\hline Carex echinochloë Kunze & Cyperaceae & & $\mathrm{H}$ & 360 \\
\hline Carex simensis Hochst. ex A. Rich. & Cyperaceae & Alanmuressa & $\mathrm{H}$ & 365 \\
\hline Carex thomasii Nelmes & Cyperaceae & Alanmuressa & $\mathrm{H}$ & 366 \\
\hline Centella asiatica (L.) Urb. & Apiaceae & Balee, Qudu & $\mathrm{H}$ & 233 \\
\hline Centhrus setigerus Vahl & Poaceae & Serdo (Amh) & $\mathrm{H}$ & 386 \\
\hline Cerastium afromontanum Th. Fr. jr. and Weimarck & Caryophyllaceae & Duqusha chuffa & $\mathrm{H}$ & 237 \\
\hline Ceropegia cufodontis Chiov. & Asclepiadaceae & Xxorso & $\mathrm{H}(\mathrm{clim})$ & 224 \\
\hline Cheilanthes farinosa (Forssk.) Kaulf. & Sinopteridaceae & & $\mathrm{H}$ & 157 \\
\hline Chiliocephalum schimperi Benth. & Asteraceae & Badubera, Muka Dadi & $\mathrm{H}$ & 204 \\
\hline Chlorophytum tenuifolium Bak. & Anthericaceae & & $\mathrm{H}$ & 315 \\
\hline Cineraria abyssinica Sch. Bip. ex A.Rich & Asteraceae & Gori Amaa, Gale Simbira & $\mathrm{H}$ & 211 \\
\hline Clematis hirsuta Perr. and Guill. & Ranunculaceae & Fitii & $\mathrm{Li}$ & 241 \\
\hline Commelina africana $\mathrm{L}$. & Commelinaceae & Gura Jarsa & $\mathrm{H}$ & 305 \\
\hline Commelina foliacea Chiov. & Commelinaceae & Marga Simbira & $\mathrm{H}$ & 78 \\
\hline Conyza tigreensis Oliv. and Hiern & Asteraceae & Anamuro, Qumbi, Darara Simbira & $\mathrm{H}$ & 210 \\
\hline Conyza variegata Sch. Bip. ex A. Rich. & Asteraceae & & $\mathrm{H}$ & 212 \\
\hline
\end{tabular}




\section{Appendix I. (Contd).}

\begin{tabular}{|c|c|c|c|c|}
\hline Scientific Name & Family & Local Name & GF & Coll.No \\
\hline Crassula alba Forssk. & Crassulaceae & Burii Jeldessa & $\mathrm{H}$ & 400 \\
\hline Crassula schimperi Fisch. and Mey & Crassulaceae & & $\mathrm{H}$ & 231 \\
\hline Craterostigma plantagineum Hochstetter & Scrophulariaceae & & $\mathrm{H}$ & 307 \\
\hline Crepis carbonaria Sch. Bip. & Asteraceae & Marga Hoffi & $\mathrm{H}$ & 218 \\
\hline Crepis ruepellii Sch. Bip. & Asteraceae & & $\mathrm{H}$ & 45 \\
\hline Cuscuta kilimanjari Oliv. & Cuscutaceae & Segeniti & $\mathrm{PH}$ & 293 \\
\hline Cyanotis polyrrhiza Hochst. ex Hassk. & Commelinaceae & & $\mathrm{H}$ & 302 \\
\hline Cycniopsis humifusa (Forssk.) Engl. & Scrophulariaceae & & $\mathrm{H}$ & 295 \\
\hline Cynoglossum amplifolium Hochst. ex DC. & Boraginaceae & Qarccabbaa & $\mathrm{H}$ & 299 \\
\hline Cynoglossum coeruleum Hochst. & Boraginaceae & Qarccabbaa & $\mathrm{H}$ & 74 \\
\hline Cyperus elegantulus Steud. & Cyperaceae & & $\mathrm{H}$ & 389 \\
\hline Cyperus platycaulis Baker & Cyperaceae & & $\mathrm{H}$ & 363 \\
\hline Cyperus rigidifolius Steud. & Cyperaceae & $\begin{array}{l}\text { Alandoo, Aladoo (Or.), } \\
\text { Engicha (Amh) }\end{array}$ & $\mathrm{H}$ & 361 \\
\hline Cyperus schimperianus Steud. & Cyperaceae & Alando & $\mathrm{H}$ & 358 \\
\hline Deschampsia caespitosa (L.) P. Beauv. & Poaceae & Looyaa, BuriiJaldeessa & $\mathrm{H}$ & 374 \\
\hline Dichondra repens J.R. and G.Frost. & Convolvulaceae & Bala Toko & $\mathrm{H}$ & 312 \\
\hline Dicrocephala chrysanthemifolia (Blume) DC. & Asteraceae & Marga Simbira & $\mathrm{H}$ & 206 \\
\hline Dicrocephala integrifolia (L.f.) Kuntze & Asteraceae & Rafu Osole & $\mathrm{H}$ & 284 \\
\hline Digitaria abyssinica (Hochst. ex A. Rich.) Stapf & Poaceae & Meqala & $\mathrm{H}$ & 378 \\
\hline Discopodium eremanthum Chiov. & Solanaceae & Meraro & $S$ & 320 \\
\hline Indigofera lupatana Bak.f. & Fabaceae & Shashamane & $\mathrm{H}$ & 245 \\
\hline Echinops hoehnelii Schweinf. & Asteraceae & Qore Haree & S & 291 \\
\hline Echinops macrochaetus Fresen. & Asteraceae & Tuqa, Qoree & $\mathrm{H}$ & 290 \\
\hline Ehrharta erecta Lam. & Poaceae & & $\mathrm{H}$ & 377 \\
\hline Eleusine floccifolia (Forssk.) Spreng. & Poaceae & Maqala (Or.), Akirima (Amh) & $\mathrm{H}$ & 351 \\
\hline Eragrostis schweinfurthii Chiov. & Poaceae & & $\mathrm{H}$ & 367 \\
\hline Erica arborea $\mathrm{L}$. & Ericaceae & Satoo & $\mathrm{S} / \mathrm{T}$ & 250 \\
\hline Erigeron alpinus L. & Asteraceae & & $\mathrm{H}$ & 285 \\
\hline Erodium moschatum (L.) Ait. & Geraniaceae & & $\mathrm{H}$ & 199 \\
\hline Euphorbia depauperata A. Rich. & Euphorbiaceae & Guri Xixiqo & $\mathrm{H}$ & 258 \\
\hline Euphorbia dumalis S. Carter & Euphorbiaceae & Gurii & $S$ & 20 \\
\hline Euphorbia platyphyllos L. & Euphorbiaceae & & $\mathrm{H}$ & 198 \\
\hline Eurynchium pulchellum (Hedw.) Jenn. & Bryophytes & Hansufe & $\mathrm{E}$ & 347 \\
\hline Felicia abyssinica Sch. Bip. ex A. Rich. & Asteraceae & & $\mathrm{H}$ & 230 \\
\hline Ferula communis L. & Apiaceae & Gnida & $\mathrm{H}$ & 257 \\
\hline Festuca richardii Alexeev & Poaceae & Yeqoq Sar (Amh) & $\mathrm{H}$ & 353 \\
\hline Festuca simensis Hochst. ex A. Rich. & Poaceae & Lancha & $\mathrm{H}$ & 382 \\
\hline Ficinia clandestina (Steud.) Bock. & Cyperaceae & Chekorsa & $\mathrm{H}$ & 357 \\
\hline Galium simense Fresen. & Rubiaceae & Maxxane (Or.), Asheket (Amh) & $\mathrm{H}$ & 251 \\
\hline Galium thunbergianum Eckl. and Zeyh. & Rubiaceae & Xooshinbaate & $\mathrm{H}$ & 238 \\
\hline Geranium arabicum Forssk. & Geraniaceae & Bucha & $\mathrm{H}$ & 265 \\
\hline Geranium kilimandscharicum Engl. & Geraniaceae & Balee Tiqo & $\mathrm{H}$ & 190 \\
\hline Gerbera piloselloides (L.) Cass. & Asteraceae & & $\mathrm{H}$ & 280 \\
\hline Gladiolus candidus (Rendle) Goldblatt & Iridaceae & Hanxxaye & $\mathrm{H}$ & 393 \\
\hline Gnaphalium rubriflorum Hilliard & Asteraceae & Badubera & $\mathrm{H}$ & 216 \\
\hline Guizotia scabra (Vis.) Chiov. & Asteraceae & Hadaa (Or.), Mech (Amh) & $\mathrm{H}$ & 209 \\
\hline Gynura pseudochina (L.) DC. & Asteraceae & Raffu & $\mathrm{H}$ & 220 \\
\hline Habenaria peristyloides A. Rich. & Orchidaceae & Kerkashaw & $\mathrm{H}$ & 309 \\
\hline Hagenia abyssinica (Bruce) J.F. Gmel. & Rosaceae & Hexxoo & $\mathrm{T}$ & 51 \\
\hline Haplocarpha rueppellii (Sch. Bip.) Beauv. & Asteraceae & & $\mathrm{H}$ & 276 \\
\hline Hebenstretia angolensis Rolfe & Scrophulariaceae & & $\mathrm{H}$ & 296 \\
\hline Helichrysum citrispinum Del. & Asteraceae & & S & 279 \\
\hline Helichrysum foetidum (L.) Moench. & Asteraceae & & $\mathrm{H}$ & 283 \\
\hline Helichrysum globosum A. Rich. & Asteraceae & & $\mathrm{H}$ & 281 \\
\hline Helichrysum gofense Cufod. & Asteraceae & Irsha & $\mathrm{H}$ & 43 \\
\hline Helichrysum harenensis Mesfin. & Asteraceae & Hoffii & $\mathrm{H}$ & 215 \\
\hline
\end{tabular}


Appendix I. (Contd).

\begin{tabular}{|c|c|c|c|c|}
\hline Scientific Name & Family & Local Name & GF & Coll.No \\
\hline Helichrysum quartinianum A. Rich. & Asteraceae & Agadena & $\mathrm{H}$ & 205 \\
\hline Helichrysum schimperi (Sch. Bip. ex A. Rich.) Moeser & Asteraceae & Badubera & $\mathrm{H}$ & 292 \\
\hline Helichrysum splendidum (Thunb.) Less. & Asteraceae & Badubera & $\mathrm{S}$ & 214 \\
\hline Helictotricon elongatum (Hochst. ex A. Rich.) C.E. Hubb. & Poaceae & Maaxaa & $\mathrm{H}$ & 373 \\
\hline Heracleum abyssinicum (Boiss.) Norman & Apiaceae & Bosoqa & $\mathrm{H}$ & 271 \\
\hline Heracleum elongense (Wolff) Bullock & Apiaceae & Qumbuta & $\mathrm{H}$ & 272 \\
\hline Heterophyllum haldanianum (Grev.) Kindb. & Bryophytes & & $\mathrm{E}$ & 346 \\
\hline Hydrocotyle mannii Hook.f. & Apiaceae & & $\mathrm{H}$ & 273 \\
\hline Hyparthelia dissoluta (Steud.) W.D. Clayton. & Poaceae & Loya & $\mathrm{H}$ & 381 \\
\hline Hypericum annulatum Moris & Hypericaceae & Sissa & $\mathrm{H}$ & 195 \\
\hline Hypericum peplidifolium A. Rich. & Hypericaceae & & $\mathrm{H}$ & 193 \\
\hline Hypericum revolutum Vahl & Hypericaceae & Garamba & $\mathrm{T} / \mathrm{S}$ & 27 \\
\hline Hypericum scioanum Chiov. & Hypericaceae & & $\mathrm{H}$ & 196 \\
\hline Impatiens rothii Hook. f. & Balsaminaceae & & $\mathrm{H}$ & 255 \\
\hline Juncus effusus L. & Juncaceae & Alando & $\mathrm{H}$ & 311 \\
\hline Juniperus procera L. & Cupressaceae & Hindessa & $\mathrm{T}$ & 53 \\
\hline Kalanchoe petitiana A. Rich. & Crassulaceae & & $\mathrm{S}$ & 28 \\
\hline Kniphofia foliosa Hochst. & Asphodelaceae & Lela & $\mathrm{H}$ & 317 \\
\hline Kniphofia insignis Rendle. & Asphodelaceae & Lela Xixiqo & $\mathrm{H}$ & 314 \\
\hline Kniphofia isoetifolia Steud. ex Hochst. & Asphodelaceae & Lela Xixiqo & $\mathrm{H}$ & 316 \\
\hline Koeleria capensis (Steud.) Nees & Poaceae & & $\mathrm{H}$ & 355 \\
\hline Kyllinga bulbosa Vahl & Cyperaceae & Qumbura & $\mathrm{H}$ & 364 \\
\hline Linum trigynum L. & Linaceae & & $\mathrm{H}$ & 225 \\
\hline Lobelia erlangeriana Engl. & Lobeliaceae & & $\mathrm{H}$ & 308 \\
\hline Lobelia holstii Engl. & Lobeliaceae & & $\mathrm{H}$ & 306 \\
\hline Lobelia neumannii T.C.E. Fries & Lobeliaceae & & $\mathrm{H}$ & 304 \\
\hline Lobularia sp.1 & Lichen & & $\mathrm{E}$ & 348 \\
\hline Lobularia sp.2 & Lichen & & $\mathrm{E}$ & 349 \\
\hline Lotus corniculatus L. & Fabaceae & Toshimbata, Qeticha & $\mathrm{H}$ & 187 \\
\hline Lotus goetzei Harms & Fabaceae & Garasita & $\mathrm{H}$ & 185 \\
\hline Lotus schoelleri Schweinf. & Fabaceae & Garasita & $\mathrm{H}$ & 275 \\
\hline Malva verticillata $\mathrm{L}$. & Malvaceae & Lita & $\mathrm{S}$ & 136 \\
\hline Maytenus obscura (A. Rich.) Cuf. & Celastraceae & Kombolcha & $\mathrm{S}$ & 208 \\
\hline Mentha aquatica L. & Lamiaceae & $\begin{array}{l}\text { Buchaa, Duqusha (Or.), Yemich } \\
\text { medihanit (Amh) }\end{array}$ & $\mathrm{H}$ & 327 \\
\hline Merendera schimperiana Hochst. & Colchicaceae & & $\mathrm{H}$ & 313 \\
\hline Microchloa kunthii Desv. & Poaceae & Marga Dima & $\mathrm{H}$ & 352 \\
\hline Microlepia speluncae (L.) Moore & Dennstaediaceae & Kumbuta & $\mathrm{H}$ & 343 \\
\hline Mikaniopsis clematoides (Sch. Bip. ex A. Rich.) Milne- & & & & \\
\hline Redh. & Asteraceae & Kumbuta & $\mathrm{Li}$ & 207 \\
\hline Minuartia filifolia (Forssk.) Mattf. & Caryophyllaceae & Qerqora, Qerqora gale & $\mathrm{H}$ & 244 \\
\hline Moraea schimperi (Hochst.) Pic.-Serm. & Iridaceae & Loga & $\mathrm{S}$ & 318 \\
\hline Myrsine melanophoeos (L.) R. Br. & Myrsinaceae & Tuullaa & $\mathrm{T}$ & 250 \\
\hline Nepeta azurea R.Br. ex Benth. & Lamiaceae & & $\mathrm{S}$ & 329 \\
\hline Oldenlandia herbacea (L.) Roxb. & Rubiaceae & Omachessaa & $\mathrm{H}$ & 228 \\
\hline Oldenlandia monanthos (A. Rich.) Hiern & Rubiaceae & Marga Dima & $\mathrm{H}$ & 229 \\
\hline Oxalis anthelmintica A. Rich. & Oxalidaceae & Soqido & $\mathrm{H}$ & 260 \\
\hline Oxalis obliquifolia A. Rich. & Oxalidaceae & & $\mathrm{H}$ & 263 \\
\hline Oxalis radicosa A. Rich. & Oxalidaceae & & $\mathrm{H}$ & 261 \\
\hline Oxystelma bornouense R. Br. & Asclepiadaceae & Xxorso, Anano & $\mathrm{H}(\mathrm{clim})$ & 201 \\
\hline Pelargonium glechomoides Hochst. & Geraniaceae & & $\mathrm{H}$ & 189 \\
\hline Pennisetum humile Hochst. ex A. Rich. & Poaceae & & $\mathrm{H}$ & 369 \\
\hline Pennisetum sphacelatum (Nees) Th. Dur. and Schinz & Poaceae & Wixxa & $\mathrm{H}$ & 380 \\
\hline Pentarrhinum balense (Liede) Liede & Asclepiadaceae & & $\mathrm{H}(\mathrm{clim})$ & 203 \\
\hline Phalaris arundinacea $\mathrm{L}$. & Poaceae & & $\mathrm{H}$ & 376 \\
\hline Pittosporum viridiflorum Sims & Pittosporaceae & Ara & $\mathrm{T}$ & 249 \\
\hline Plantago africana Verdc. & Plantaginaceae & Qinxaa, Baallee & $\mathrm{H}$ & 297 \\
\hline Plectocephalus varians (A. Rich.) C. Jeff. ex Cuf. & Asteraceae & Qumbura & $\mathrm{H}$ & 277 \\
\hline
\end{tabular}




\section{Appendix I. (Contd).}

\begin{tabular}{|c|c|c|c|c|}
\hline Scientific Name & Family & Local Name & GF & Coll.No \\
\hline Plectranthus puberulentus J.H. Morton & Lamiaceae & Biranbira & $\mathrm{H}$ & 336 \\
\hline Pleopeltis macrocarpa (Willd.) Kaulf & Polypodiaceae & & $\mathrm{E}$ & 342 \\
\hline Poa schimperiana Hochst. ex A. Rich. & Poaceae & & $\mathrm{H}$ & 371 \\
\hline Pollichia campestris Ait. & Caryophyllaceae & & $\mathrm{H}$ & 235 \\
\hline Polygala steudneri Chod. & Polygalaceae & Garasita & $\mathrm{H}$ & 186 \\
\hline Polypogon schimperianus (Hochst. ex Steud.) Cope & Poaceae & & $\mathrm{H}$ & 354 \\
\hline Polystichum ammifolium (Poir.) C.Chr. & Dryopteridaceae & Qumbuta, Gammanyee & $\mathrm{H}$ & 338 \\
\hline Pseudognaphalium luteo-album (L.) Hilliard and Burtt & Asteraceae & & $\mathrm{H}$ & 282 \\
\hline Ranunculus multifidus Forssk. & Ranunculaceae & Sherif & $\mathrm{H}$ & 267 \\
\hline Ranunculus simensis Fresen. & Ranunculaceae & & $\mathrm{H}$ & 268 \\
\hline Rosa abyssinica Lindley & Rosaceae & Gora & S & 142 \\
\hline Rubus apetalus Poir. & Rosaceae & & S & 262 \\
\hline Rubus erlangeri Engl. & Rosaceae & Hato & S & 202 \\
\hline Rubus steudneri Schwienf. & Rosaceae & Gora & S & 14 \\
\hline Rumex abyssinicus Jacq. & Polygonaceae & Shabee Haga & $\mathrm{H}$ & 269 \\
\hline Rumex nepalensis Spreng. & Polygonaceae & Shabee & $\mathrm{H}$ & 29 \\
\hline Rytidosperma subulata (A. Rich.) Cope & Poaceae & Marga Hori, Qecha & $\mathrm{H}$ & 359 \\
\hline Salvia merjame Forssk. & Lamiaceae & Okotu & S & 330 \\
\hline Salvia nilotica Jacq. & Lamiaceae & Okotu & $\mathrm{H}$ & 332 \\
\hline Sanicula elata Buch. -Ham. ex D.Don & Apiaceae & Galee Simbira, Sidissa & $\mathrm{H}$ & 270 \\
\hline Satureja biflora (Don.) Briq. & Lamiaceae & Tosign & $\mathrm{H}$ & 335 \\
\hline Satureja kilimandeschari (Gurke) Hedberg & Lamiaceae & & $\mathrm{H}$ & 324 \\
\hline Satureja pseudosimensis Brenan & Lamiaceae & Toshimbata & $\mathrm{H}$ & 325 \\
\hline Satureja punctuta (Benth.) Briq. & Lamiaceae & & $\mathrm{H}$ & 326 \\
\hline Satureja simensis (Benth.) Briq. & Lamiaceae & Toshimbata & $\mathrm{H}$ & 328 \\
\hline Scabiosa columbaria $\mathrm{L}$. & Dipsacaceae & Anamuro & $\mathrm{H}$ & 222 \\
\hline Sedum baleensis M. Gilbert & Crassulaceae & Qorso gogorii & $\mathrm{H}$ & 274 \\
\hline Senecio ochrocarpus Oliv. and Hiern & Asteraceae & Agadena & $\mathrm{H}$ & 278 \\
\hline Senecio ragazzii Chiov. & Asteraceae & Agadena & $\mathrm{H}$ & 221 \\
\hline Silene macrosolen A. Rich. & Caryophyllaceae & Wagarti & $\mathrm{H}$ & 248 \\
\hline Solanum anguivi Lam. & Solanaceae & Mujule Worabessa & S & 69 \\
\hline Solanum benderianum Schimper ex Dammer & Solanaceae & & S & 322 \\
\hline Solanum garae Friis & Solanaceae & & S & 321 \\
\hline Solanum marginatum L.f. & Solanaceae & Hidii & S & 68 \\
\hline Sonchus bipontini Aschers & Asteraceae & Kartassa, Maaracaa & $\mathrm{H}(\mathrm{clim})$ & 288 \\
\hline Sporobolus africanus (Poir.) Robyns and Tournay & Poaceae & $\begin{array}{l}\text { Marga Hilensa (Or.), Mure (Amha) } \\
\text { Qorsa alati, Merga simbira, Qoricha }\end{array}$ & & 350 \\
\hline Stachys alpigena T.C.E.Fries & Lamiaceae & gemogi, Dara simbira & $\mathrm{H}$ & 334 \\
\hline Stellaria media (L.) Vill. & Caryophyllaceae & Mosiye (Amh) & $\mathrm{H}$ & 226 \\
\hline Stellaria sennii Chiov. & Caryophyllaceae & Duqushu, Dinbiba & $\mathrm{H}$ & 239 \\
\hline Thalictrum rhynchocarpum Dill. and A. Rich. & Ranunculaceae & Sire Bizu (Amh) & $\mathrm{H}$ & 254 \\
\hline Thymus schimperi Ronniger & Lamiaceae & Tossigne & $\mathrm{H}$ & 331 \\
\hline Trifolium burchellianum Ser. & Fabaceae & & $\mathrm{H}$ & 183 \\
\hline Trifolium substerraneum $\mathrm{L}$. & Fabaceae & Sidissa & $\mathrm{H}$ & 184 \\
\hline Trifolium cryptopodium Steud. ex A. Rich. & Fabaceae & & $\mathrm{H}$ & 194 \\
\hline Trifolium rueppellianum Fresen. & Fabaceae & Sidissa (Maget) & $\mathrm{H}$ & 182 \\
\hline Trifolium semipilosum Fresen. & Fabaceae & Sidissa & $\mathrm{H}$ & 181 \\
\hline Trifolium simense Fresen. & Fabaceae & & $\mathrm{H}$ & 247 \\
\hline Lychnis abyssinica (Hochst.) Lidén & Caryophyllaceae & Balee & $\mathrm{H}$ & 240 \\
\hline Ursinia nana DC. & Asteraceae & Qinxxa & $\mathrm{H}$ & 219 \\
\hline Urtica simensis Steudel & Urticaceae & Dobii & $\mathrm{H}$ & 252 \\
\hline Usnea africana Motyka & Lichen & Ye' Abuye tsim & $\mathrm{E}$ & 344 \\
\hline Verbascum benthamianum Hepper & Scrophulariaceae & Rafuu Mada & $\mathrm{H}$ & 323 \\
\hline Vicia sativa $\mathrm{L}$. & Fabaceae & & $\mathrm{H}$ & 197 \\
\hline Viola abyssinica Oliv. & Violaceae & & $\mathrm{H}$ & 337 \\
\hline Zehneria scabra (Linn.f.) Sond. & Cucurbitaceae & Harola & $\mathrm{H}(\mathrm{clim})$ & 124 \\
\hline
\end{tabular}


Appendix II. Dendrogram output of the cluster analysis showing the five communities and respective plots.

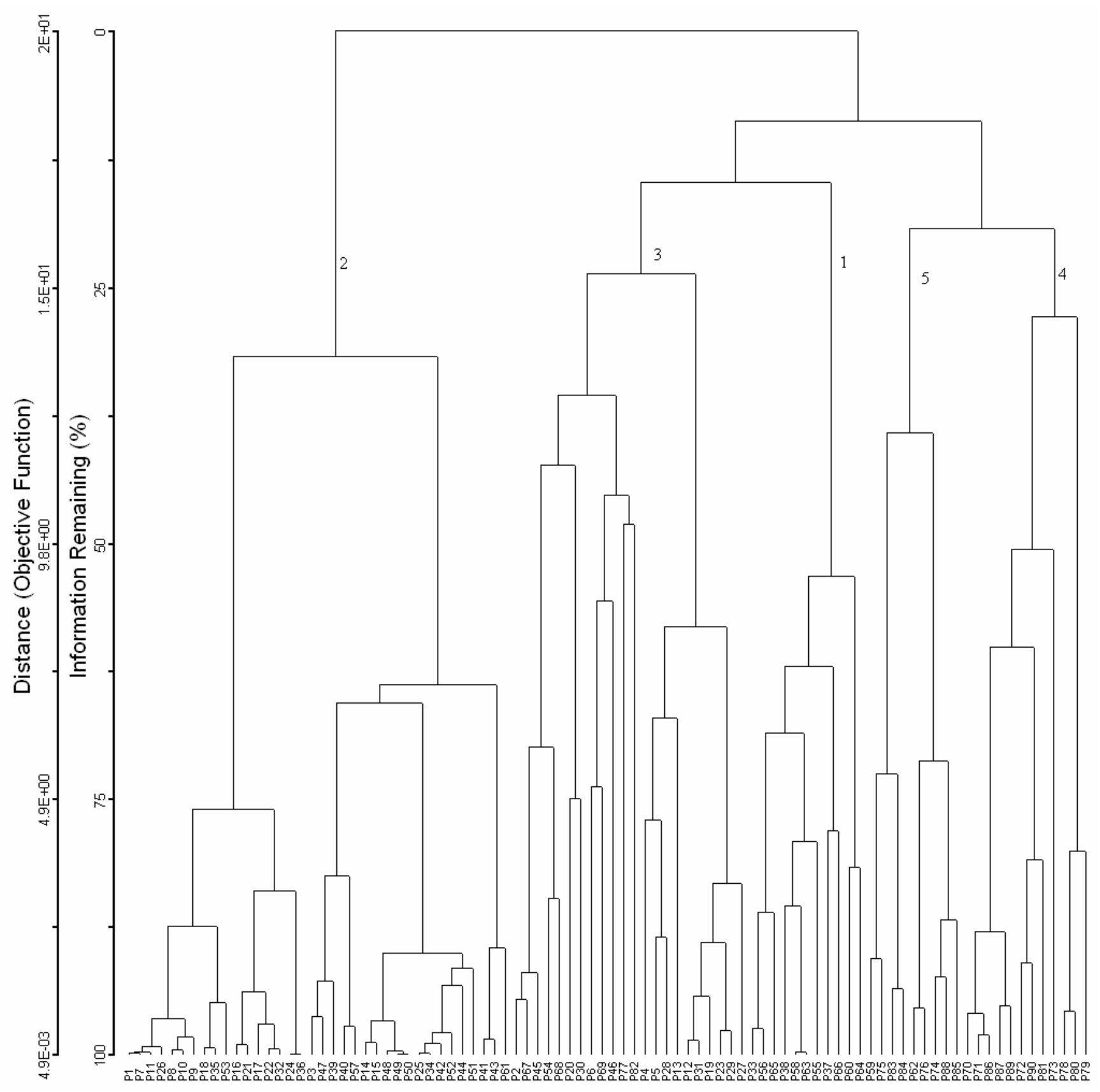

